\title{
Guillain-Barré syndrome associated with arboviruses in the state of Pernambuco in 2016
}

\author{
Síndrome de Guillain-Barré associada à arboviroses \\ no estado de Pernambuco em 2016
}

\section{Síndrome de Guillain-Barré asociado a arbovirosis en el Estado de Pernambuco en 2016}

\section{Jacihony Aline Oliveira ${ }^{[a]}$, Márcia Fabiana Ferreira Firmino®[a], Dominique Babini Albquerque Cavalcanti@[a,b]*}

[a] Centro Universitário Maurício de Nassau (Uninassau), Recife, PE, Brazil

${ }^{[b]}$ Universidade Federal de Pernambuco (UFPE), Recife, PE, Brazil

\section{Abstract}

Introduction: In 2016, Brazil presented an increase in the notifications related to neurological syndromes with previous register of a febrile illness compatible with arboviruses, including Guillain-Barré syndrome (GBS). Such disease is responsible for the most frequent occurrence of flaccid paralysis in the world, causing bilateral ascending muscle weakness that might affect the respiratory tract. Objective: To investigate the incidence of Guillain-Barré syndrome associated with arboviruses in Pernambuco in 2016 and to describe the confirmed/probable cases. Method: This is an observational retrospective study of GBS cases with a background of infection from dengue, chikungunya, or Zika virus notified to the Pernambuco Health State Secretariat (SES-PE). Cases notified from January $1^{\text {st }}$ to December $31^{\text {st }}, 2016$ were included, which were considered as possible GBS at the time of notification. The suspect cases were investigated and classified

* JAO: BS, email: jacihony@hotmail.com MFFF: MS, email: fisiomarciaf@gmail.com DBAC: Doctoral student, email: dbabini.fisioterapeuta@gmail.com 
as confirmed/probable by the positive laboratory test result, excluding the possibility of infection. Results: Forty-three suspect cases of GBS after previous arbovirus infection were notified. From these, 23 were classified as confirmed/probable for the etiological agents chikungunya and/or dengue. The mean age of the affected individuals was $37.22 \pm 21.29$ years and they were mostly female (56.5\%). The annual incidence of GBS after arbovirus infection was 0.24 cases per 100 thousand inhabitants in the state. The neurological condition was mainly characterized by the presence of movement $(91.3 \%)$ and walking $(78.3 \%)$ alterations. Conclusion: The findings of this research confirm the current set of evidence and show the likelihood of GBS being a severe neurological complication of these arboviruses.

Keywords: Guillain-Barré Syndrome. Dengue. Chikungunya Virus. Zika Virus.

\section{Resumo}

Introdução: No Brasil, em 2016, houve aumento das notificações relacionadas às síndromes neurológicas com registro anterior de doença febril compatível com infecção por arboviroses, dentre elas a Síndrome de GuillainBarré (SGB). Trata-se da ocorrência mais frequente de paralisia flácida no mundo, causa fraqueza muscular bilateral ascendente e pode atingir as vias respiratórias. Objetivo: Analisar a incidência da Síndrome de GuillainBarré associada à arboviroses em Pernambuco no ano de 2016 e descrever os casos confirmados/prováveis. Método: Trata-se de um estudo observacional retrospectivo dos casos de SGB com histórico de infecção prévia por dengue, chikungunya ou vírus Zika, notificados à Secretaria Estadual de Saúde de Pernambuco (SES-PE). Foram incluídos casos notificados de 1ํo de janeiro a 31 de dezembro de 2016 considerados suspeitos de SGB no momento da notificação. Os casos suspeitos foram investigados e classificados como confirmados/prováveis através de resultado de exame laboratorial positivo, excluída a possibilidade de infecção. Resultados: Foram notificados 43 casos suspeitos de SGB após infecção prévia por arbovírus. Destes, 23 foram classificados como confirmados/prováveis para os agentes etiológicos chikungunya e/ou dengue, sendo a média de idade igual a $37,22 \pm 21,29$ anos e maioria do sexo feminino (56,5\%). A incidência anual de SGB após infecção por arbovírus foi de 0,24 casos por 100 mil habitantes no estado. O quadro neurológico foi caracterizado prioritariamente pela presença de alterações motoras (91,3\%) e na marcha (78,3\%). Conclusão: Os achados da presente pesquisa acrescentam ao conjunto de evidências sobre a possibilidade de a SGB se apresentar como uma grave complicação neurológica dessas arboviroses.

Palavras-chave: Síndrome de Guillain-Barré. Dengue. Vírus Chikungunya. Zika Vírus.

\section{Resumen}

Introducción: En Brasil, en 2016, hubo aumento de las notificaciones relacionadas con los síndromes neurológicos con registro anterior de enfermedad febril compatible con infección por arbovirosis, entre ellas el Síndrome de Guillain-Barré (SGB). Se trata de la aparición más frecuente de parálisis flácida en el mundo, causa debilidad muscular bilateral ascendente y puede alcanzar las vías respiratorias. Objetivo: Analizar la incidencia del Síndrome de Guillain-Barré asociada a los arbovirosis en Pernambuco en el año 2016 y describir los casos confirmados / probables. Método: Se trata de un estudio observacional retrospectivo de los casos de SGB con antecedentes de infección previa por dengue, chikungunya o virus Zika, notificados a la Secretaría Estatal de Salud de Pernambuco (SES-PE). Se incluyeron casos notificados del 1 de enero al 31 de diciembre de 2016 considerados sospechosos de SGB en el momento de la notificación. Los casos sospechosos fueron investigados y clasificados como confirmados / probables a través del resultado de un examen de laboratorio positivo, excluida la posibilidad de infección por otros agentes virales. Resultados: Se han notificado 43 casos sospechosos de SGB tras la infección previa por arbovirus. De estos, 23 fueron clasificados como confirmados / probables para los agentes etiológicos chikungunya y / o dengue, siendo la media de edad igual a 37,22 $\pm 21,29$ años y la mayoría del sexo femenino (56,5\%). La incidencia anual de SGB tras infección por arbovirus fue de 0,24 casos por 100 mil habitantes en el estado. El cuadro neurológico fue caracterizado prioritariamente por la 
presencia de alteraciones motoras (91,3\%) y en la marcha (78,3\%). Conclusión: Los hallazgos de la presente investigación añaden al conjunto de evidencias sobre la posibilidad de que la SGB se presente como una grave complicación neurológica de esas arbovirosis.

Palabras clave: Síndrome de Guillain-Barré. Dengue. Virus Chikungunya. Virus Zika.

\section{Introduction}

In 2015, three pathogenic arboviruses circulated in Brazil with sustained urban concentration: dengue, chikungunya, and Zika [1]. Since the mid1980 s, dengue has been registered in the country. This characterized its re-emergence, while the appearance of chikungunya and Zika viruses is more recent, confirmed in 2014 and 2015, respectively [2].

In 2016, the country saw an increase in the notifications related to neurological syndromes with previous register of febrile disease compatible with arbovirus infections [3]. The occurrence of neurological syndromes, mainly GuillainBarré syndrome after infectious processes, has been described in the literature and is more commonly associated with Campylobacter infections, influenza virus, Epstein-Barr virus, HIV, pneumonias, among other diseases $[4,5]$. The triple epidemic of arboviruses, characterized by the occurrence in the state of Pernambuco of dengue, Zika, and chikungunya cases, made this scenery more complex because these diseases are also associated with the possibility of occurrence of post-infection neurological manifestations [6].

The confirmation of arboviral neuroinvasive disease cases, initially related to Zika virus (2015) and later to chikungunya (2016), led the Pernambuco Health State Secretariat (SES-PE) to create the "Arbovirus Neuroinvasive Disease Sentinel Surveillance" in May 2016. This agency was officialized through the technical note $\mathrm{n}^{\text {o }}$ 08/2016 by the Health Executive Surveillance Secretariat (SEVS) and the Ordinance SES no 390 of 14/09/2016, and adds diseases, hazards, and events in the state to the Mandatory Notification National List, also proposing other measures [3].

GBS is an autoimmune neurological syndrome in which around $60 \%$ of the cases can be ascribed to recent infectious conditions $[7,8]$, causing bilateral ascending muscle weakness and flaccid paralysis, which usually starts in the lower limbs and might even reach the respiratory tract $[9,10]$. The GBS physiopathological process, including inflammatory demyelination, seems to involve immunological factors, with synergic participation of cell and humoral immunity [11]. Molecular mimicry is the probable mechanism that triggers the inflammatory infection process in GBS [12]. The immune response against the infectious agent results in the production of antibodies that recognize epitopes similar to those in the microorganism in the peripheral nerve, triggering the immune attack to it [13].

This disease presents the most frequent occurrence of flaccid paralysis in the world, with annual incidence of 0.16 to 4.0 cases per 100.000 people and with minimum seasonal variation [14]. GBS might occur at any age. However, in the United States of America and Europe, the incidence tends to increase with age, while in China the illness prevails in children, mainly its axonal variant [10]. In normal situations, most cases occur sporadically and seem not to present seasonality, while the lethality rate might range between $5 \%$ and $15 \%$ $[15,16]$.

The occurrence of GBS in Brazil increased 19\% between January and November 2015, according to the World Health Organization (WHO), compared to the average of the previous years. The total number of patients met with this autoimmune disease in the period was 1,708 , which corresponds to over five cases a day

[17]. In Pernambuco, 127 GBS cases were registered after viral infection in 2015; in the previous year, only 21 cases had been recorded, which represents a $500 \%$ increase in the incidence. GBS diagnosis was confirmed in 46 cases, and the association between the syndrome and the possibility of previous infection by Zika virus was observed in 22 of them [18]. 
This study aimed to investigate the incidence of Guillain-Barré syndrome associated with arboviruses in Pernambuco in 2016, to describe the confirmed/probable cases regarding clinical and personal characterization of the etiological agent, and to evaluate the distribution of the number of cases of arboviruses and GBS notified per week throughout the epidemics.

\section{Methods}

This is a retrospective observational study of GBS cases with a previous background of infection from dengue, chikungunya, or Zika viruses, notified to SEVS at the SES-PE by one of the sentinel hospital units, namely: Correia Picanço, Mestre Vitalino, and Restauração. The included cases were those notified from January $1^{\text {st }}$ to December $31^{\text {st }}, 2016$ in the state of Pernambuco, which were considered suspect for GBS at the moment of the notification (GBS diagnostic hypothesis; admission in one of the sentinel hospital units; and viral infection background compatible with dengue, chikungunya, or Zika symptoms up to 30 days before the onset of the neurological symptoms).

Suspect cases were investigated and classified as confirmed/probable by positive laboratory test results: after detection of zika, dengue, and chikungunya viruses; or with IgM serology or RTPCR reagent per blood sample or LCR for zika, dengue or chikungunya, excluding the possibility of infection, in the same period, by other viral agents that might also cause GBS. If any other GBS-causing etiology was confirmed (such as Campylobacter, Influenza virus, Epstein-Barr virus, HIV) or another clinical diagnosis was presented, the case was dismissed.

After approval by the Ethics Committee of Research on Human Beings of the University Center Maurício de Nassau, under Opinion no 2.130.904, SES-PE provided the researchers with data recorded in the notification forms of neuroinvasive diseases related to arboviruses from the database of GBS notifications.

Data analysis was carried out using the Statistical Package for the Social Sciences (SPSS) 20.0 for Windows. The following testes were applied: Kolmogorov-Smirnov, to analyze the distribution of variances; and Bartlett, to verify the homogeneity of variances. Kruskal-Wallis test was conducted to analyze the differences of age mean and time median of the infection-start of the neurological condition between the different types of etiological agents. Fisher exact test was used to identify category variables. A $5 \%$ level of significance was considered.

The notified cases of arbovirus infection with GBS diagnostic hypothesis according to the etiological agent, the neurological manifestations of the GBS confirmed/probable cases per etiological agent, and the characterization of confirmed/ probable cases regarding sex and age range were described based on frequency.

To calculate the incidence rate of GBS associated with arbovirus, the number of cases in 2016 in Pernambuco was divided by the number of inhabitants in that state and multiplied by 100.000 .

\section{Results}

Out of the 129 suspect cases of neuroinvasive diseases notified in the state of Pernambuco in 2016, 43 cases (35.8\%) presented GBS diagnostic hypothesis and its undetermined origin variants, while the remaining 77 cases (64.2\%) corresponded to other diagnostic hypothesis of neuroinvasive diseases related to arboviruses, such as: myelitis, meningoencephalitis, encephalitis, myeloneuropathy, and myeloradiculitis.

Most of the cases with GBS diagnostic hypothesis were notified by the sentinel unit Hospital da Restauração (88.4\%), and the municipalities with most notifications of GBS suspect cases were Jaboatão dos Guararapes (23.2\%) and Recife (20.9\%). Figure 1 shows the distribution of the number of dengue, chikungunya, and zika notified cases and GBS notified cases per epidemiological week in the state of Pernambuco in 2016, considering the period from the first to the fifty-second epidemiological weeks, according to the Event and Notification Information System (SINAN) and FormSUS (a form created by the Brazilian Unified Health System). A certain overlap of notifications of the three arboviruses in a time sequence was observed along with the prevalence of notified cases with GBS diagnostic hypotheses, according to the onset of symptoms in the 29/2016 epidemiological week (Figure 1). The months with most notified cases were July (39.5\%) and June (25.6\%). 


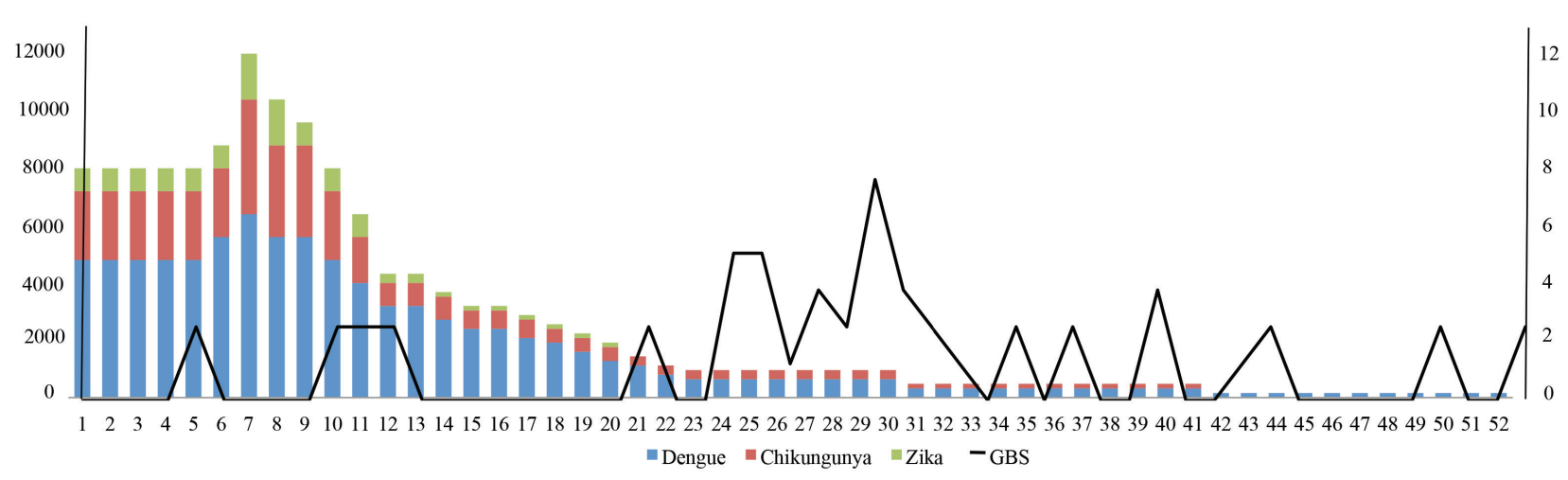

Note: Adapted from the Neuroinvasive Diseases associated with arboviruses Weekly Follow-up Spreadsheet and FormSUS.

Figure 1 - Time distribution of arbovirus cases (dengue, chikungunya and zika) and GBA, considering the date of the start of symptoms in Pernambuco, weeks 1 to 52/2016.

Laboratory tests for etiological diagnosis were carried out following the notified cases. Examinations were carried out for the relevant arboviruses in the epidemiological scenery of Pernambuco: dengue, chikungunya, and acute disease caused by the Zika virus. A Table 1 shows the distribution of notified cases with GBS diagnostic hypothesis according to the etiological agent of the confirmed cases.
It seems relevant to point out that 11 cases were classified as inconclusive, since the samples did not meet the technical requirements regarding time of collection or the laboratory results did not allow etiological identification.

Considering only the total number of confirmed/ probable cases, the annual incidence of GBS after arbovirus infection was 0.24 cases per 100 thousand inhabitants in the population under study.

Table 1 - Distribution of the notified cases with GBS diagnostic hypothesis, according to the etiological agent, in the cases confirmed in Pernambuco in 2016

\begin{tabular}{lcc}
\hline \multirow{2}{*}{ Final classification for etiological diagnosis } & $\mathbf{n}$ & $\mathbf{2 0 1 6}$ \\
\cline { 2 - 3 } Confirmed $^{1}$ chikungunya & 2 & \% \\
Probable $^{2}$ chikungunya & 13 & 4.8 \\
Probable $^{2}$ dengue & 5 & 30.2 \\
Probable $^{2}$ dengue/chikungunya & 3 & 11.6 \\
Dismissed & 7 & 6.7 \\
Inconclusive & 11 & 16.3 \\
Under investigation & 2 & 25.6 \\
\hline
\end{tabular}

Note: Adapted from the Neuroinvasive Diseases associated with arboviruses Weekly Follow-up Spreadsheet and FormSUS.

n: frequency; \%: percentage; ${ }^{1}$ Confirmed cases: RT-PCR technique; ${ }^{2}$ Probable cases: IGM technique or Triage Test.

Regarding the sex of the patients with GBS diagnostic hypothesis, 22 (51.2\%) were women and $21(48.8 \%)$ were men. The mean age of the individuals whose cases were notified was $40.55 \pm 24.34$ years and the time median between the arbovirus infection and the onset of neurological symptoms was 13 $\left(\mathrm{IQ}_{25-75} \% 2-42\right)$ days.

When considering only the confirmed/probable cases, $13(56.5 \%)$ of the patients were women and 10
$(43.5 \%)$ were men, and the mean age of the patients whose cases were confirmed/probable GBS was $37.22 \pm 21.29$ years. Table 2 shows the distribution of GBS confirmed/probable cases according to age, time between infection and onset of the neurological condition, and sex of the patients per etiological agent. No statistically significant difference was observed between the different etiological agents regarding the variables investigated. 
Table 2 - Characterization of GBS confirmed/probable cases according to age, time between infection and onset of neurological condition, sex, and age range of the patients, per etiological agent in Pernambuco in 2016

\begin{tabular}{|c|c|c|c|c|}
\hline \multirow{2}{*}{ Characterization } & \multicolumn{4}{|c|}{ Confirmed/Probable cases } \\
\hline & Chik & Den & Den/Chik & \\
\hline \multirow{3}{*}{ Age (years) } & mean $\pm s d$ & mean $\pm s d$ & mean $\pm s d$ & $p$-value* \\
\hline & $44.20 \pm 22.74$ & $23.00 \pm 11.57$ & $26.00 \pm 6.08$ & 0.142 \\
\hline & (IQ25-75\%) & (IQ25-75\%) & (IQ25-75\%) & \\
\hline \multirow[t]{2}{*}{ Time between infection and onset of the neurological condition (days) } & $13(7-19.5)$ & $4(3-5)$ & $6(4-11)$ & 0.483 \\
\hline & n (\%) & n (\%) & n (\%) & $\mathrm{p}$-value** \\
\hline \multicolumn{5}{|l|}{ Sex } \\
\hline Female & $7(46.7)$ & $4(80.0)$ & $2(66.7)$ & \multirow{2}{*}{0.399} \\
\hline Male & $8(53.3)$ & $1(20.0)$ & $1(33.3)$ & \\
\hline \multicolumn{5}{|l|}{ Age range (years) } \\
\hline $0-9$ & $1(6.7)$ & $1(20.0)$ & $0(0.0)$ & \multirow{7}{*}{0.324} \\
\hline $10-19$ & $3(20.0)$ & $1(20.0)$ & $1(33.3)$ & \\
\hline $20-29$ & $0(0.0)$ & $1(20.0)$ & $1(33.3)$ & \\
\hline $30-39$ & $1(6.7)$ & $2(40.0)$ & $1(33.3)$ & \\
\hline $40-49$ & $1(6.7)$ & $0(0.0)$ & $0(0.0)$ & \\
\hline $50-59$ & $5(33.3)$ & $0(0.0)$ & $0(0.0)$ & \\
\hline 60 and over & $4(26.7)$ & $0(0.0)$ & $0(0.0)$ & \\
\hline
\end{tabular}

Note: Adapted from the Neuroinvase Diseases associated with arboviruses Weekly Follow-up Spreadsheet and FormSUS.

Chik: Chikungunya; Den: Dengue; sd: standard deviation; IQ: interquartile; n: frequency; \%: percentage. *Kruskal-Wallis; **Fisher exact test. 5\% significance level.

When all notified suspect cases of GBS associated with arboviruses in Pernambuco in 2016 were considered, $37(86.1 \%)$ presented movement alterations and 36 (83.7\%), walking alterations. Among the confirmed/ probable cases, $21(91.3 \%)$ presented movement alterations, while $18(78.3 \%)$ had walking alterations.
Table 3 shows the distribution of neurological manifestations in the GBS confirmed/probable cases per etiological agent. No statistically significant difference was found between the different etiological agents for the variables investigated.

Table 3 - Neurological manifestations in GBS confirmed/probable cases, per etiological agent, in Pernambuco in 2016

\begin{tabular}{lcccc}
\hline \multirow{2}{*}{ Neurological manifestation } & \multicolumn{3}{c}{ Confirmed /Probable cases } \\
\cline { 2 - 5 } & $\begin{array}{c}\text { Chik } \\
\mathbf{n}(\%)\end{array}$ & $\begin{array}{c}\text { Den } \\
\mathbf{n}(\%)\end{array}$ & $\begin{array}{c}\text { Den/Chik } \\
\mathbf{n}(\%)\end{array}$ & p-value* \\
\hline Movement alteration & $14(93.3)$ & $5(100.0)$ & $2(66.7)$ & 0.241 \\
Walking alteration & $11(73.3)$ & $4(80.0)$ & $3(100.0)$ & 0.590 \\
Awareness alteration & $3(20.0)$ & $1(20.0)$ & $0(0.0)$ & 0.695 \\
Behavior alteration & $1(6.7)$ & $0(0.0)$ & $0(0.0)$ & 0.757 \\
Sensitiveness alteration & $1(6.7)$ & $1(20.0)$ & $1(33.3)$ & 0.399 \\
Visual alteration & $2(13.3)$ & $0(0.0)$ & $0(0.0)$ & 0.558 \\
Seizure & $1(6.7)$ & $0(0.0)$ & $0(0.0)$ & 0.757 \\
Vertigo / Dizziness & $3(25.0)$ & $0(0.0)$ & $1(33.3)$ & 0.437 \\
\hline
\end{tabular}

Note: Adapted from the Neuroinvasive Diseases associated with arboviruses Weekly Follow-up Spreadsheet and FormSUS.

Chik: Chikungunya; Den: Dengue; n: frequency; \%: percentage.

*Fisher exact test. $5 \%$ significance level.

Regarding the evolution of the GBS notified cases, 29 (67.44\%) were discharged from hospital.
Out of those, 20 (46.51\%) presented sequelae at the moment of discharge. Two patients were transferred 
to another health service, three notifications did not evolve, and nine cases evolved to death, four with background of viral infection from chikungunya and one from dengue.

\section{Discussion}

Previous evidence suggests the association between arbovirus infection and GBS [19-25]. Regarding the frequent and intense dengue, chikungunya, and Zika epidemics, there are few cases described involving neurological complications associated with infection by these viruses. This might be explained by the fact that it rarely attacks the nervous central system, unlike other arboviruses [26].

Five probable cases of GBS after dengue were registered in this research, and another three were associated with dengue/chikungunya. Some previous reports described GBS in individuals with dengue, highlighting that the same pro-inflammatory substances that are present in the immune response to the dengue virus also played an important role in the GBS physiopathology, establishing a relation between both conditions $[27,28]$. The immune response provoked by dengue might react in a crossed way with the peripheral nerve components, because of the sharing of cross-reactive epitopes. Such immune response might be directed to the myelin or the peripheral nerve axon [29].

After outbreaks in the region of Micronesia and French Polynesia in 2007, reports of neurological complications after Zika virus infection started to be described in the literature [30]. The increase in the notification of the number of GBS cases with previous viral infection background was observed after the identification of the Zika virus, confirmed for the first time in Brazil in 2015 [31]. A study carried out in Rio de Janeiro, from December 2015 to March 2016, identified 20 cases of GBS, from which 17 presented viral disease background with a clinical condition similar to that of the Zika virus [32].

There was no confirmation of GBS cases related to Zika virus in the period under investigation, possibly because of the technical characteristics of the tests available to identify that virus and the temporal opportunity of collection. The identification by the RT-PCR technique requires a sample (blood/CSF) preferably collected up to the first day of the start of the viral infection symptoms. Due to the existence of asymptomatic Zika virus acute events $(80 \%$ of cases) and the neurological conditions appearing with a time interval between 8 and 15 days after the viral condition, the absence of confirmation for this etiological agent is justified.

There is a smaller number of GBS case reports after chikungunya compared to those reported for dengue and Zika virus [33]. However, 15 confirmed/ probable post-chikungunya GBS cases were recorded in this research, totaling $35.0 \%$ of the notified cases. This fact is due to the chikungunya endemic outbreak registered in Brazil. From 2015 to 2016, the probable cases of infection increased from 36,200 thousand to 271,824 thousand, a $627 \%$ increase. In 2016 , the virus attacked mainly the Northeast region, with 47,300 thousand notified cases in Pernambuco and 58 deaths caused by it [34]. Out of the five deaths registered in the State due to GBS associated with arboviruses, four were related to chikungunya previous infection.

A study carried out in the French Polynesia recorded nine GBS cases during a six-month outbreak of chikungunya in 2015, which represents an increased incidence from four to nine times and suggests that GBS is not an unusual possibility in neurological conditions associated with chikungunya virus infection in an epidemic context [35].

The time interval between the start of the previous viral infection symptoms and the neurological condition recorded confirms the results of previous studies [36, 37]. The peak of GBS cases notified occurred between June and July, similarly to a study carried out in Bahia in 2015 [38]. This time distribution is believed to be justified by the fact that the national protocol for the investigation of GBS cases following dengue, chikungunya, and Zika virus was only established in late 2015 [39]. Thus, the inclusion of serologies for these agents in the etiological research on GBS cases, pursuant to the protocol defined by the Ministry of Health, started in 2016, and the first few months were a period of creation of a State flow of implementation of the national recommendation, which gives room to a possible underestimation of GBS cases from arboviruses in the first quarter of 2016, when the highest number of arbovirus cases was recorded in Pernambuco.

The first neurological alterations found in GBS cases associated with arboviruses referred to movement and walking, which is in accordance 
with previous findings $[25,33,40]$. A study carried out in France in 2009 reported two GBS cases after chikungunya; the patients were a 48 and 51-year-old women, presenting progressive movement weakness, lack of tendon reflex, and sensory disorder [25]. In 2016, in Colombia, a case was reported in which a 77-year-old woman presented progressive movement weakness and sensory disorder after chikungunya infection [40]. In India, in 2017, two other cases of GBS after chikungunya were reported in men, aged 18 and 30 years old, and presenting limb and face muscle weakness and dysphagia [33].

The GBS neurological condition does not seem to differ in cases of previous infection from dengue or chikungunya. This study did not find statistically significant differences. A case study carried out in 2015 in Sri Lanka reported a 34-year-old man with previous dengue infection, presenting difficulties to walk at admission, lower and upper limb hypotonia, and areflexia with sensory integrity [41]. In 2016, three cases were reported in New Caledonia, in which two men and a woman, aged between 55 and 68 years old, presented GBS after dengue with ascending muscle weakness, tetraparesis, and walking disorder. Two of them also presented cranial nerve palsy with dysphagia and bilateral face paralysis [22].

It seems relevant to emphasize the importance of the availability of suitable tests to identify Zika virus and the collection of samples in the preferable time period after the onset of the viral infection symptoms, which are limiting factors in this research.

\section{Conclusion}

The arbovirus diseases dengue, chikungunya, and Zika appear among the main endemic infections in Brazil, with important impact on health at a national level. The findings of this research add to the current set of evidence the possibility that GBS is a serious neurological complication from these arboviruses. The suspicion of such complication should justify the implementation and management of strategies for notification and suitable investigation of the GBS suspect cases and other neurological manifestations possibly associated with arbovirus in Brazilian municipalities and states. Considering the severity of the cases, one must pay attention to the suitability of the clinical management and availability of intensive care beds to fight these events.

\section{References}

1. Figueiredo LTM. The recent arbovirus disease epidemic in Brazil. Rev Soc Bras Med Trop. 2015;48(3):233-4.

2. Malta JMAS, Varga A, Leite PL, Percio J, Coelho GE, Ferraro AHA, et al. Síndrome de Guillain-Barré e outras manifestações neurológicas possivelmente relacionadas à infecção pelo vírus zika em municípios da Bahia, 2015. Epidemiol Serv Saude. 2017;26(1):9-18.

3. Secretaria de Saúde do Estado de Pernambuco. Secretaria Executiva de Vigilância em Saúde. Diretoria Geral de Controle de Doenças e Agravos. Nota Técnica DG-CDA nำ16/2017. Atualização da nota técnica SEVS no 08/2016. Vigilância sentinela das doenças neuroinvasivas relacionadas às arboviroses de importância para saúde pública. Recife: Secretaria Estadual de Saúde; 2017.

4. Kuwabara S, Yuki N. Axonal Guillain-Barré syndrome: concepts and controversies. Lancet Neurol. 2013;12(12):1180-8.

5. Cao-Lormeau VM, Blake $\mathrm{A}$, Mons $\mathrm{S}$, Lastère $\mathrm{S}$, Roche C, Vanhomwgen J., et al. Guillain-Barré Syndrome outbreak associated with Zika virus infection in French Polynesia: a case-control study. Lancet. 2016;387:1531-9.

6. Secretaria de Saúde do Estado de Pernambuco. Secretaria Executiva de Vigilância em Saúde. Informe técnico doença neuroinvasiva relacionada às arboviroses período de referência: SE 01 à 52/2016. Recife: Secretaria Estadual de Saúde; 2017.

7. Sejvar JJ, Baughman AL, Wise M, Morgan OW. Population incidence of Guillain-Barré syndrome: a systematic review and meta-analysis. Neuroepidemiology. 2011;36(2):123-33.

8. Hugh JW, Bart CJ, Pieter AVD. Guillain-Barré syndrome: a systematic review. Lancet. 2016;388(10045):717-27.

9. Rajabally YA, Unicini A. Outcome and its predictors in Guillain-barré syndrome. J Neurol Neurosurg Psychiatry. 2012;83(7):711-18. 
10. González-Suárez I, Sanz-Gallego I, Rivera FJR, Arpa J. Guillain-Barré Syndrome: natural history and prognostic factors: a retrospective review of 106 cases. BMC Neurol. 2013;13:95.

11. van den Berg B, Walgaard C, Drenthen J, Fokke C, Jacobs BC, Van Doorn PA. Guillain-Barré syndrome: pathogenesis, diagnosis, treatment and prognosis. Nat Rev Neurol. 2014;10(8):469-82.

12. Yuki N, Hartung HP. Guillain-Barre syndrome. N Engl J Med. 2012;366(24):2294-304.

13. Yoshikawa H. Epidemiology of Guillain-Barré Syndrome. Brain Nerve. 2015;67(11):1305-11.

14. Dourado MET Jr. Síndrome de Guillain-Barré: epidemiologia, prognóstico e fatores de risco. [Tese]. Natal: Universidade Federal do Rio Grande do Norte; 2015.

15. Sejvar JJ, Kohl KS, Gidudu J, Amato A, Bakshi N, Baxter R, et al. Guillain-Barré syndrome and Fisher syndrome: case definitions and guidelines for collection, analysis, and presentation of immunization safety data. Vaccine. 2011;29(3):599-612.

16. Brasil. Ministério da Saúde. Secretaria de Vigilância em Saúde. Departamento de Vigilância das doenças transmissíveis. Protocolo de vigilância e resposta à ocorrência de microcefalia e/ou alterações do sistema nervoso central (SNC). Brasília, DF; 2015.

17. World Health Organization. Zika virus infection: global update on epidemiology and potentially associated clinical manifestations. Wkly Epidemiol Rec. 2016;91(7):73-88.

18. Secretaria de Saúde do Estado de Pernambuco. Superintendência de Comunicação. Guillain-Barré: aumento de 500\%. Recife: Secretaria Estadual de Saúde; 2015.

19. Fragoso YD, Gomes S, Brooks JB, Matta APC, Guillain-Barre syndrome: Tauil CB, et al. Guillain-Barré syndrome and dengue fever: report on ten new cases in Brazil. Arq Neuro-Psiquiatr. 2016;74(12):1039-40.
20. Petersen LR, Jamieson DJ, Powers AM, Honein MA. Zika virus. N Engl J Med. 2016;374(16):1552-63.

21. Qureshi NK, Begum A, Saha PR, Hossain MI. GuillainBarre syndrome following dengue fever in adult patient. J Med. 2012;13:246-9.

22. Simon O, Billot S, Guyon D, Daures M, Descloux E, Gourinat AC, et al. Early Guillain-Barré Syndrome associated with acute dengue fever. J Clin Virol. 2016;77:29-31.

23. Muñoz LS, Barreras P, Pardo CA. Zika virus-associated neurological disease in the adult: Guillain-Barré syndrome, encephalitis, and myelitis. Semin Reprod Med. 2016;34(5):273-9.

24. Tournebize P, Charlin C, Lagrange M. Neurological manifestations in Chikungunya: about 23 cases collected in Reunion Island. Rev Neurol. 2009;165(1):48-51.

25. Lebrun $G$, Chadda $K$, Reboux $A H$, Martinet 0 , Gaüzère BA. Guillain-Barré Syndrome Chikungunya Infection. Emerg Infect Dis. 2009;15(3):495-6.

26. Cunha-Matta AP, Soares-Moreno SA, Almeida AC, Freitas VA, Carod-Artal FJ. Complicaciones neurológicas de la infección por el virus del dengue. Rev. Neurol 2004;39(3):233-7.

27. Braga EL, Moura P, Pinto LM, Ignacio SR, Oliveira MJ, Cordeiro MT, et al. Detection of circulant tumor necrosis factor-alpha, soluble tumor necrosis factor p75 and interferon-gamma in Brazilian patients with dengue fever and dengue hemorrhagic fever. Mem Inst Oswaldo Cruz. 2001;96(2):229-32.

28. Willison HJ, Jacobs BC, van Doorn PA. Guillain-Barré syndrome. Lancet. 2016;388(10045):717-27.

29. Carod-Artal FJ, Wichmann O, Farrar J, Gascon J. Neurological complications of dengue virus infection. Lancet Neurol. 2013;12(9):906-19.

30. Brasil. Ministério da Saúde. Secretaria de Vigilância em Saúde. Febre pelo vírus Zika: uma revisão narrativa sobre a doença. Bol Epidemiol. 2015;46(26):1-7. 
31. Cardoso CW, Paploski IAD, Kikuti M, Rodrigues MS, Silva MMO, Campos GE, et al. Outbreak of exanthematous illness associated with Zika, Chikungunya, and Dengue viruses, Salvador, Brazil. Emerg Infect Dis. 2015;21(12):2274-6.

32. Silva IRF, Frontera JA, Nascimento OJM. News from the battlefront: Zika virus associated Guillain-Barré syndrome in Brazil. Neurology. 2016;87(15):e180-1.

33. Agarwal A, Vibha D, Srivastava AK, Shukla G, Prasad K. Guillain-Barre syndrome complicating chikungunya virus infection. J Neurovirol. 2017;23(3):504-7.

34. Brasil. Ministério da Saúde. Secretaria de Vigilância em Saúde. Boletim Epidemiológico. 2017;48(5):1-9.

35. Oehler E, Fournier E, Leparc-Goffart I, Larre P, Cubizolle $S$, Sookhareea $C$, et al. Increase in cases of GuIllain-Barré Syndrome during a chikungunya outbreak, French Polynesia, 2014 a 2015. Euro Surveill. 2015;20(48):30079.

36. Newswanger DL, Warren CR. Guillain-Barré syndrome. Am Fam Physician. 2004;69(10):2405-10.

37. Kuwabara S. Guillain-Barré Syndrome: epidemiology, pathophysiology and management. Drugs. 2004;64(6):597-610.
38. Malta JMAS, Vargas A, Leite PL, Percio J, Coelho GE, Ferraro AHA, et al. Síndrome de GuillainBarré e manifestações neurológicas possivelmente relacionadas ao vírus Zika em municípios da Bahia, 2015. Epidemiol Serv Saude. 2017;26(1):9-18.

39. Brasil. Ministério da Saúde. Secretaria de Vigilância em Saúde. Departamento de Vigilância das Doenças Transmissíveis. Protocolo de vigilância dos casos de manifestações neurológicas com histórico de infecção viral prévia. Brasília, DF; 2015.

40. Villamil-Gómez W, Silvera LA, Páez-Castellanos J, Rodriguez-Morales AJ. Guillain-Barré syndrome after Chikungunya infection: a case in Colombia. Enferm Infecc Microbiol Clin. 2016;34(2):140-1.

41. Ralapanawa DMPUK, Kularatne SAM, Jayalath WATA. Guillain-Barre syndrome following dengue fever and literature review. BMC Res Notes. 2015;8:729.

Received in 01/13/2018

Recebido em 13/01/2018

Recibido en 13/01/2018

Approved in 03/07/2019 Aprovado em 07/03/2019 Aprobado en 07/03/2019 